\title{
Kajian Kerentanan Wilayah Pesisir Ditinjau dari Geomorfologi dan Elevasi Pesisir Kota dan Kabupaten Jayapura, Provinsi Papua
}

\author{
Baigo Hamuna ${ }^{1}$ \\ Jurusan IImu Kelautan dan Perikanan, Fakultas Matematika dan IImu Pengetahuan Alam \\ Universitas Cenderawasih, Jayapura, Indonesia
}

\section{Annisa Novita Sari}

Jurusan Perencanaan Wilayah dan Kota, Fakultas Teknik Universitas Cenderawasih, Jayapura, Indonesia

\author{
Alianto \\ Jurusan Perikanan, Fakultas Perikanan dan IImu Kelautan \\ Universitas Papua, Manokwari, Indonesia \\ Artikel Masuk : 9 Juli 2017 \\ Artikel Diterima : 7 Desember 2017 \\ Tersedia Online : 29 April 2018
}

\begin{abstract}
Abstrak: Wilayah pesisir Kota dan Kabupaten Jayapura yang berhadapan langsung dengan Samudera Pasifik dengan pemanfaatan multifungsi merupakan wilayah yang rentan terhadap bencana. Kerentanan wilayah pesisir dapat ditentukan dengan memperhatikan beberapa faktor yang mempengaruhinya, di antaranya adalah aspek geomorfologi (penggunaan lahan) dan elevasi. Tujuan penelitian ini adalah untuk menentukan indeks kerentanan pesisir Kota dan Kabupaten Jayapura yang difokuskan pada aspek geomorfologi dan elevasi pesisir dalam meminimalkan dampak kerusakan pesisir. Wilayah kajian sepanjang 241,86 km, terletak di sepanjang wilayah pesisir Kota dan Kabupaten Jayapura. Metode yang dilakukan dalam penelitian ini yaitu mengumpulkan data geomorfologi dan elevasi pesisir, kemudian menentukan nilai indeks kerentanan pesisir yang dibagi menjadi lima kelas kategori kerentanan pesisir. Hasil penelitian menunjukkan bahwa sepanjang 145,88 km (61,18\%) wilayah pesisir termasuk kategori tidak rentan, 33,14 km (13,90\%) termasuk kategori kurang rentan, 29,03 km (12,17\%) termasuk kategori sedang, $12,12 \mathrm{~km}(5,08 \%)$ termasuk kategori rentan, dan sisanya $18,29 \mathrm{~km}(7,67 \%)$ termasuk kategori sangat rentan. Wilayah pesisir Kota Jayapura memiliki tingkat kerentanan dalam kategori tidak rentan, sedang dan rentan, sedangkan wilayah pesisir Kabupaten Jayapura tergolong dalam kategori tidak rentan dan sedang. Wilayah pesisir yang paling rentan adalah wilayah pesisir Distrik Abepura, Distrik Jayapura Selatan, dan Distrik Muaratami, Kota Jayapura. Adapun wilayah pesisir dengan elevasi yang tinggi termasuk kategori tidak rentan.
\end{abstract}

Kata kunci: elevasi, geomorfologi, indeks kerentanan pesisir, Kota dan Kabupaten Jayapura

\footnotetext{
${ }^{1}$ Korespondensi Penulis: Jurusan Ilmu Kelautan dan Perikanan, Fakult as Matematika dan Ilmu Pengetahuan Alam Universit as Cenderawasih, Jay apura, Indonesia

Email: bhamuna@yahoo.com.sg
} 


\title{
2 Kajian Kerentanan Wilayah Pesisir Ditinjau dari Geomorfologidan Elevasi Pesisir...
}

\begin{abstract}
The coastal areas of both Jayapura Municipality and Regency which is directly opposite to the Pacific Ocean with the multifunctional use is a vulnerable area to disasters. The coastal vulnerability is determined by considering some influential factors, that is geomorphology and elevation to minimize the coastal damage impacts. The purpose of this study is to determine the coastal vulnerability index of Jayapura City and Regency focusing on the coastal geomorphology and elevation. The study area covers a coastal area of 241.86 $\mathrm{km}$ along the coastlines of Jayapura Municipality and Regency. The study method includes data collection on the coastal geomorphology and elevation characteristics. The value of coastal vulnerability index of each parameter is determined by dividing into five categories of coastal vulnerability. The result shows territorial division as follows: $145.88 \mathrm{~km}(61.18 \%)$ was not vulnerable, $33.14 \mathrm{~km}(13.90 \%)$ was less vulnerable, $29.03 \mathrm{~km}(12.17 \%)$ was a moderate vulnerability, $12.12 \mathrm{~km}(5.08 \%)$ was vulnerable, and the remaining $18.29 \mathrm{~km}(7.67 \%)$ was very vulnerable. The coastal vulnerability of Jayapura City coastal areas categorized into three classes, i.e. not vulnerable, moderate vulnerable and vulnerable, while the Jayapura Regency coastal areas felt into the following classes: not vulnerable and moderate vulnerable. The most vulnerable areas were of Abepura District, South Jayapura District and Muaratami District, all in the Jayapura Municipality administration. Those areas with high elevation level were not vulnerable at all.
\end{abstract}

Keywords: coastal vulnerability index, elevation, geomorphology, Jayapura Municipality and Regency

\section{Pendahuluan}

Wilayah pesisir merupakan kawasan peralihan atau pertemuan antara darat dan laut yang secara fisik merupakan suatu kawasan yang sempit. Apabila dilihat dari potensinya, wilayah pesisir merupakan wilayah yang kaya akan potensi sumber daya hayati maupun nonhayati, baik yang berada pada mintakat di daratan maupun pada mintakat perairannya. Aktivitas ekonomi dan tekanan penduduk yang berasosiasi dengan keinginan masyarakat dalam rangka peningkatan kesejahteraan pada akhirnya akan memanfaatkan ruang spasial yang tersedia. Pesisir sebagai wilayah yang relatif mudah dijangkau akan menjadi sasaran untuk pengembangan aktivitas manusia (Marfai \& King, 2008; Ward, Marfai, Yulianto, Hizbaron, \& Aerts, 2011).

Mengingat wilayah pesisir memiliki peranan yang sangat strategis sekaligus rentan terhadap perubahan lingkungan dan aktivitas manusia, maka dalam pemanfaatan kawasan pesisir perlu dicari keseimbangan optimum antara pemanfaatan, pengelolaan dan pelestariannya. Secara umum, upaya perlindungan, pelestarian, dan pemanfaatan wilayah pesisir di Indonesia sesuai dengan ketentuan yang terdapat dalam Pasal 28 UndangUndang Nomor 27 Tahun 2007 (Pemerintah Republik Indonesia, 2007) dan dalam Peraturan Menteri Kelautan dan Perikanan Republik Indonesia Nomor 23 Tahun 2016 tentang Perencanaan Pengelolaan Wilayah Pesisir dan Pulau-Pulau Kecil (KKP, 2016). Pengelolaan wilayah pesisir dan pulau-pulau kecil meliputi kegiatan perencanaan, pemanfaatan, pengawasan, dan pengendalian terhadap interaksi manusia dalam memanfaatkan sumber daya pesisir dan pulau-pulau kecil serta proses alamiah secara berkelanjutan dalam upaya meningkatkan kesejahteraan masyarakat dalam menjaga keutuhan Negara Kesatuan Republik Indonesia. Salah satu bentuk rencana pengelolaan pesisir adalah upaya untuk mengindentifikasi permasalahan yang terjadi di wilayah pesisir, baik dari aspek fisik maupun aspek sosial wilayah pesisir.

Permasalahan di wilayah pesisir sangat sensitif dan rentan terhadap fenomena alam. Menurut Kaly, Pratt, \& Mitchell (2004), wilayah pesisir merupakan suatu wilayah yang lemah atau rentan terhadap faktor lingkungan seperti variabilitas iklim, perubahan iklim dan terhadap naiknya permukaan laut. Dampak yang diterima wilayah pesisir akibat fenomena ini merupakan hal yang perlu dikaji untuk mengidentifikasi secara spasial tingkat 
kerentanan pantai dan memproyeksikan perubahan kerentanan wilayah pesisir di masa yang akan datang. Salah satu aspek yang berpengaruh dalam penilaian proses kerentanan wilayah pesisir terhadap kenaikan muka air laut adalah bentuk geomorfologi dan elevasi wilayah pesisir. Geomorfologi atau bentuk lahan pesisir menandakan ketahanan suatu wilayah pesisir terhadap erosi dan akresi akibat kenaikan muka air laut. Terkait dengan dampak kenaikan muka air laut, tipe bentuk lahan perlu diketahui untuk mengindikasikan bentuk ketahanan atau resistensi suatu bagian pantai atau pesisir terhadap erosi atau akresi sebagai akibat kenaikan muka laut (Pendleton, Thieler, \& Williams, 2005), sedangkan elevasi atau ketinggian wilayah pesisir berkaitan dengan kelemahan wilayah pesisir terhadap bahaya genangan dan kecepatan maju atau mundurnya garis pantai. Proses lainnya yang dapat berpengaruh terhadap tingkat kerentanan wilayah pesisir antara lain laju perubahan garis pantai, kemiringan pantai, gelombang, pasang surut dan kenaikan muka air laut (Agustin, Syamsidik, \& Fatimah, 2016; Joesidawati, 2016; Sakka, Paharuddin, \& Rupang, 2014).

Terkait kerentanan wilayah pesisir di Indonesia, beberapa penelitian telah dilakukan untuk mengkaji tingkat kerentanan di wilayah pesisir Indonesia seperti yang dilakukan oleh Prabowo \& Astjario (2012), yang mengkaji kerentanan di wilayah pesisir Pulau Jawa dengan hasil bahwa kenaikan muka air laut dengan kecepatan 2-8 mm/tahun dalam 100 tahun mendatang mampu untuk menggenangi kawasan pesisir Pulau Jawa yang memiliki morfologi pantai yang landai dan bersudut lereng kecil dan menimbulkan bencana pada daerah rawan, rentan, bahkan berisiko mengalami kenaikan muka air laut. Sakka et al. (2014) menganalisis tingkat kerentanan pesisir Kota Makassar, menyebutkan bahwa parameter yang sangat berpengaruh terhadap kerentanan pantai di Kota Makassar adalah kemiringan dasar pantai dan perubahan garis pantai, di sepanjang pantai Kota Makassar yang memiliki kerentanan tinggi berkisar $7 \mathrm{~km}$ pada pesisir Kecamatan Tamalate. Putra, Husrin, Tanto, \& Pratama (2015) berpendapat bahwa kerentanan pesisir timur laut Bali disebabkan oleh penggunaan lahan yang terlalu dekat dengan garis pantai dan gelombang tinggi yang signifikan sehingga pesisir timur laut Bali dikategorikan wilayah dengan tingkat kerentanan tinggi.

Hasil penelitian tersebut memberikan gambaran yang nyata tentang kerentanan beberapa wilayah pesisir di Indonesia. Kondisi saat ini sebagian besar wilayah pesisir menghadapi berbagai tekanan dan perkembangan serta perubahan, tidak terkecuali wilayah pesisir Kota dan Kabupaten Jayapura. Dinamika wilayah pesisir yang tinggi akan membawa implikasi pada kehidupan dan pembangunan kawasan terutama pada perkembangan kotakota pesisir. Terutama wilayah pesisir Kota Jayapura yang merupakan pusat pemerintahan dan perekonomian Jayapura, termasuk pusat pembangunan di Provinsi Papua yang sedang berkembang. Perkembangan Kota Jayapura yang bervariasi sebagian terjadi melalui proses tertentu yang dipengaruhi oleh faktor fisik dan nonfisik. Wilayah pesisir semakin menghadapi tekanan tinggi dari aktivitas alami dinamika pesisir termasuk angin dan gelombang yang berdampak pada dinamika bentang lahan (Beatley, Brower, \& Schwab, 2002). Berdasarkan data Rencana Tata Ruang Wilayah (RTRW) Kota Jayapura 2013-2033 sepanjang 27,58 km kawasan pesisir pantai Kota Jayapura terancam oleh adanya bencana abrasi yang disebabkan oleh gelombang air laut (Pemerintah Kota Jayapura, 2013). Selain itu, wilayah pesisir juga menerima berbagai dampak yang disebabkan oleh aktivitas manusia (Fletcher \& Smith, 2007). Menurut Marfai \& King (2008) dan Abidin et al. (2010), beban bangunan serta ekstraksi air tanah besar-besaran yang menyebabkan penurunan permukaan tanah dan dapat berdampak lebih burukjika terjadi kenaikan muka air laut.

Mengingat bahwa kondisi fisik wilayah pesisir Kota dan Kabupaten Jayapura berhadapan langsung dengan laut lepas (Samudera Pasifik) dan semakin tingginya aktivitas pembangunan serta pemanfaatan wilayah pesisir Kota dan Kabupaten Jayapura, maka secara tidak langsung wilayah pesisir Kota dan Kabupaten Jayapura merupakan wilayah yang rentan terhadap bencana di wilayah pesisir, termasuk akibat perubahan iklim global. 


\section{Kajian Kerentanan Wilayah Pesisir Ditinjau dari Geomorfologidan Elevasi Pesisir...}

Melihat kondisi tersebut, maka penelitian ini dilakukan dengan tujuan untuk menganalisis dan menentukan tingkat kerentanan wilayah pesisir Kota dan Kabupaten Jayapura secara spasial dengan menggunakan aspek geomorfologi (tutupan lahan) dan elevasi wilayah pesisir sebagai parameter kajian. Penelitian ini sangat penting dilakukan untuk memprediksi kawasan pesisir Kota dan Kabupaten Jayapura yang rentan, terutama terhadap kenaikan muka laut. Hasil dari penelitian ini diharapkan dapat memberikan gambaran awal wilayah pesisir Kota dan Kabupaten Jayapura yang rentan terhadap dampak perubahan iklim, sehingga dapat dijadikan sebagai input dalam perencanaan pembangunan dan pengelolaan wilayah pesisir secara baik.

\section{Metode Penelitian}

\section{Lokasi Penelitian}

Wilayah kajian dalam penelitian ini meliputi wilayah pesisir Kota Jayapura dan Kabupaten Jayapura, Provinsi Papua. Wilayah kajian mengikuti garis pantai sepanjang 238,46 km (106,06 km Kota Jayapura dan 132,40 km Kabupaten Jayapura) yang membentang dari perbatasan RI-PNG hingga perbatasan Kabupaten Jayapura dengan Kabupaten Sarmi serta mencakup 4 distrik pesisir di Kota Jayapura (Distrik Muaratami, Distrik Abepura, Distrik Jayapura Selatan dan Distrik Jayapura Utara) dan 4 distrik di Kabupaten Jayapura (Distrik Raveni Rara, Distrik Depapre, Distrik Yokari dan Distrik Demta). Wilayah kajian dibatasi sejauh 500 meter dari garis pantai dan dibagi menjadi 107 sel untuk memudahkan dalam proses analisis.

\section{Pengumpulan Data}

Variabel fisik pesisir yang dijadikan masukan dalam mengkaji kerentanan pesisir dibatasi hanya pada bentuk geomorfologi dan elevasi pesisir. Data yang digunakan dalam penelitian ini antara lain (1) tata guna lahan wilayah Jayapura skala 1:250.000 yang diperoleh dari Badan Informasi Geospasial (BIG), (2) peta tutupan lahan Indonesia tahun 2012, (3) peta wilayah Jayapura skala 1:250.000 yang dikeluarkan oleh Kementerian Kehutanan 2013, (4) citra Shuttle Radar Topography Mission (SRTM) cakupan wilayah Jayapura. Perangkat lunak yang digunakan antara lain (1) Global Mapper 13 untuk analisis citra SRTM, (2) ArcGIS 10.5 untuk analisis spasial, dan (3) Microsoft Excel untuk tabulasi data.

\section{Analisis Data}

Tahapan analisis data untuk menentukan tingkat kerentanan wilayah pesisir sebagai berikut:

1. Mengelompokkan data vektor geomorfologi atau tutupan lahan dan tingkat elevasi pesisir berdasarkan kelas atau kategori kerentanannya. Data tutupan lahan dikelompokkan menjadi 6 kelompok yaitu (1) daratan alluvial, (2) rawa payau, (3) hutan bakau, (4) bangunan pantai, (5) estuari, laguna, delta, dan (6) pantai berpasir (Sakka \& Muzaki, 2010), sedangkan tingkat elevasi dikelompokkan menjadi 5 kelompok ketinggian yaitu (1) 0-5 meter; (2) 5-10 meter; (3) 10-20 meter; (4) 20-30 meter; dan (5) >30 meter (Gornitz, 1991; Pendleton et al., 2005).

2. Transformasi data dalam bentuk numerik. Data geomorfologi merupakan variabel non-numerik dikonversi menjadi variabel numerik, sehingga harus diubah menggunakan matriks transformasi untuk memperoleh data numerik variabel geomorfologi berupa ranking yang mewakili resistensi masing-masing kelompok pada bentuk lahan geomorfologi. 
3. Analisis tingkat kerentanan secara spasial dengan melakukan overlay semua variabel vektor (tutupan lahan dan elevasi) serta cakupan wilayah kajian sebagai pembatas. Analisis tingkat kerentanan wilayah pesisir dari bentuk geomorfologi dan elevasi wilayah pesisir Kota Jayapura dan Kabupaten Jayapura dianalisis berdasarkan perhitungan kriteria kerentanan (Tabel 1).

4. Perhitungan indeks kerentanan wilayah pesisir Kota dan Kabupaten Jayapura ditentukan dengan mengkombinasikan nilai kedua aspek tersebut (tutupan lahan dan elevasi) untuk menghasilkan indikator kerentanan. Perhitungan nilai skor indeks kerentanan dilakukan berdasarkan konsep perhitungan nilai indeks kerentanan dalam metode Coastal Vulnerability Index (CVI). Metode CVI menerapkan pendekatan yang sederhana dalam penyediaan dasar numerik untuk klasifikasi bagian-bagian dari garis pantai terhadap perubahan fisik sehingga dapat digunakan dalam mengidentifikasi wilayah berisiko tinggi. Secara umum, indeks kerentanan berdasarkan persamaan berikut (Gornitz, 1990; Pendleton, Thieler, \& Williams, 2010):

$$
\mathrm{CVl}=\sqrt{\frac{a \times b}{2}}
$$

dengan, CVI $=$ nilai indeks kerentanan, $a$ dan $b$ adalah bobot variabel geomorfologi dan elevasi.

5. Pembagian tingkat kerentanan wilayah pesisir berdasarkan pembagian indeks mengacu pada Gornitz \& White (1992), dilakukan berdasarkan persen dengan kisaran antarkelas kategori adalah $20 \%$. Oleh karena aspek yang dikaji hanya bentuk geomorfologi dan elevasi pesisir dengan nilai indeks kerentanan maksimun 3,55 (apabila kedua variabel sangat rentan) dan minimum 0,7 (apabila kedua variabel tidak rentan), sehingga pembagian skor indeks kerentanan wilayah pesisir pada penelitian ini sebagai berikut:
1. Kelas Tidak Rentan
$: 0,70-1,27$
2. Kelas Kurang Rentan
$:>1,27-1,84$
3. Kelas Sedang
$:>1,84-2,41$
4. Kelas Rentan
$:>2,41-2,98$
5. Kelas Tidak Rentan
$:>2,98-3,55$

Tabel 1. Kriteria Tingkat Kerentanan Aspek Geomorfologi dan Elevasi Pesisir

\begin{tabular}{|c|c|c|c|c|c|c|}
\hline \multirow[t]{2}{*}{ No } & \multirow[t]{2}{*}{ Variabel } & $\begin{array}{c}\text { Tidak } \\
\text { Rentan }\end{array}$ & $\begin{array}{l}\text { Kurang } \\
\text { Rentan }\end{array}$ & Sedang & Rentan & Sangat Rentan \\
\hline & & Skor 1 & Skor 2 & Skor 3 & Skor 4 & Skor 5 \\
\hline 1. & $\begin{array}{l}\text { Geomorfologi } \\
\text { (Tutupan } \\
\text { Lahan) }\end{array}$ & $\begin{array}{l}\text { Bertebing } \\
\text { tinggi }\end{array}$ & $\begin{array}{l}\text { Bertebing } \\
\text { sedang, } \\
\text { pantai } \\
\text { berlekuk }\end{array}$ & $\begin{array}{l}\text { Bertebing } \\
\text { rendah, } \\
\text { dataran } \\
\text { alluvial }\end{array}$ & $\begin{array}{l}\text { Bangunan } \\
\text { pantai, pantai, } \\
\text { estuari, laguna }\end{array}$ & $\begin{array}{l}\text { Penghalang pantai, } \\
\text { pantai berpasir, } \\
\text { berlumpur, mangrove, } \\
\text { delta, karang, lamun }\end{array}$ \\
\hline 2. & $\begin{array}{l}\text { Elevasi } \\
\text { Pesisir (m) }\end{array}$ & $>30$ & $20,1-30,0$ & $10,1-20,0$ & $5,1-10,0$ & $0-5,0$ \\
\hline
\end{tabular}

Sumber: Gornitz, 1990; Pendleton et al, 2005 


\section{Kajian Kerentanan Wilayah Pesisir Ditinjau dari Geomorfologidan Elevasi Pesisir...}

\section{Hasil Pembahasan}

\section{Tingkat Kerentanan Geomorfologi Pesisir}

Secara umum, tutupan dan penggunaan lahan wilayah Provinsi Papua didominasi oleh hutan. Berdasarkan data BPS tahun 2011 yang diacu dalam Dwiprabowo, Djaenudin, Alviya, \& Wicaksono (2014), bahwa penggunaan lahan di Provinsi Papua didominasi oleh kawasan hutan $(78,71 \%)$, yang kemudian diikuti dengan pekarangan dan tegalan. Dari peta tutupan lahan pada Gambar 1, tutupan lahan Kota dan Kabupaten Jayapura berupa hutan, semak belukar atau savana, pemukiman dan perkebunan, serta dataran alluvial yang dimanfaatkan sebagai sawah dan tegalan atau ladang. Selain tutupan lahan tersebut, pantai berpasir juga ditemukan hampir sepanjang pantai Distrik Abepura dan Distrik Jayapura Selatan (kecuali bagian barat dalam Teluk Youtefa) serta sebagian kecil pantai Distrik Depapre di Kabupaten Jayapura, dan pantai berlumpur terbentang sepanjang pantai Distrik Muaratami. Pantai berbatu terdapat pada sebagian pantai Distrik Jayapura Utara hingga sepanjang pantai pesisir Kabupaten Jayapura. Adapun ekosistem pesisir, seperti terumbu karang dan lamun hanya terdapat pada titik-titik tertentu, yaitu pada perairan utara Distrik Jayapura Utara dan Distrik Depapre, hal ini dapat disebabkan karena banyaknya aliran sungai, baik berukuran besar maupun kecil yang bermuara di sepanjang pantai dan bentuk topografi pantai yang terjal hingga sangat terjal yang tidak memungkinkan tumbuh dan berkembangnya terumbu karang. Mangrove hanya terdapat dan tumbuh dengan baik di kawasan pesisir Teluk Youtefa (Distrik Abepura dan Distrik Jayapura Selatan) serta Distrik Demta.

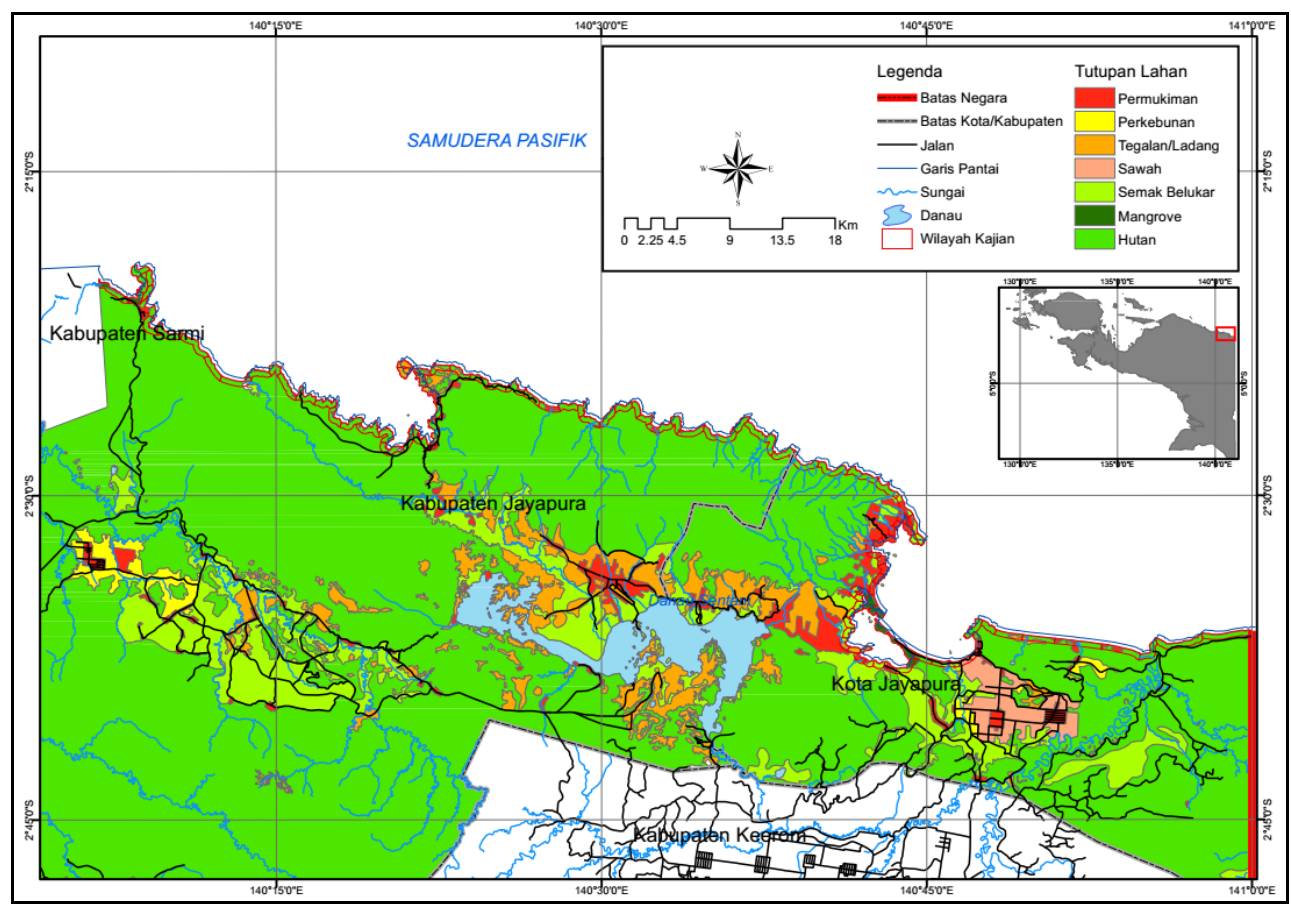

Sumber: Hasil Analisis, 2017

Gambar 1. Peta Tutupan Lahan Kota dan Kabupaten Jayapura

Dari hasil analisis tingkat kerentanan tutupan lahan setiap sel wilayah kajian pada Gambar 2, sekitar 59,53\% (141,96 km) wilayah kajian termasuk dalam kategori tidak rentan, kategori kurang rentan 10,77\% (25,68 km), kategori sedang 14,29\% (34,08 km), 
kategori rentan 7,3\% (17,47 km), dan kategori sangat rentan 8,08\% $(19,27 \mathrm{~km})$. Tingkat kerentanan tutupan lahan pesisir Kota Jayapura lebih bervariatif. Berdasarkan tutupan lahannya, wilayah pesisir yang termasuk dalam kategori sangat rentan dan rentan merupakan wilayah pesisir dengan tutupan lahan berupa vegetasi mangrove dan pemukiman. Menurut Syah (2013), bahwa kondisi mangrove yang tipis akan membuat daerah tersebut rentan dan mudah mengalami genangan. Sejalan dengan pernyataan tersebut, maka kawasan mangrove di Kota Jayapura akan semakin rentan karena kondisi mangrove telah banyak mengalami kerusakan dan semakin tipis akibat penebangan. Lebih lanjut, dari hasil pengelompokkan kerentanan tutupan lahan, kategori sangat rentan dan rentan banyak ditemukan di sepanjang pesisir Kota Jayapura yang disebabkan karena wilayah pesisir Kota Jayapura merupakan kawasan pusat berbagai aktitas (pemerintahan, pembangunan, perekonomian dan pariwisata) dibandingkan Kabupaten Jayapura yang terpusat di sekitar kawasan Danau Sentani yang terletak jauh dari wilayah pesisir. Selain itu, beberapa titik pemukiman di wilayah pesisir Kabupaten Jayapura berada pada wilayah perbukitan. Wilayah pesisir yang termasuk dalam kategori tidak rentan dan kurang rentan merupakan wilayah pesisir yang sebagian besar berupa perbukitan atau dataran dataran tinggi yang terdapat hampir di sepanjang wilayah pesisir Kabupaten Jayapura dan pesisir utara Distrik Jayapura Utara, Kota Jayapura.

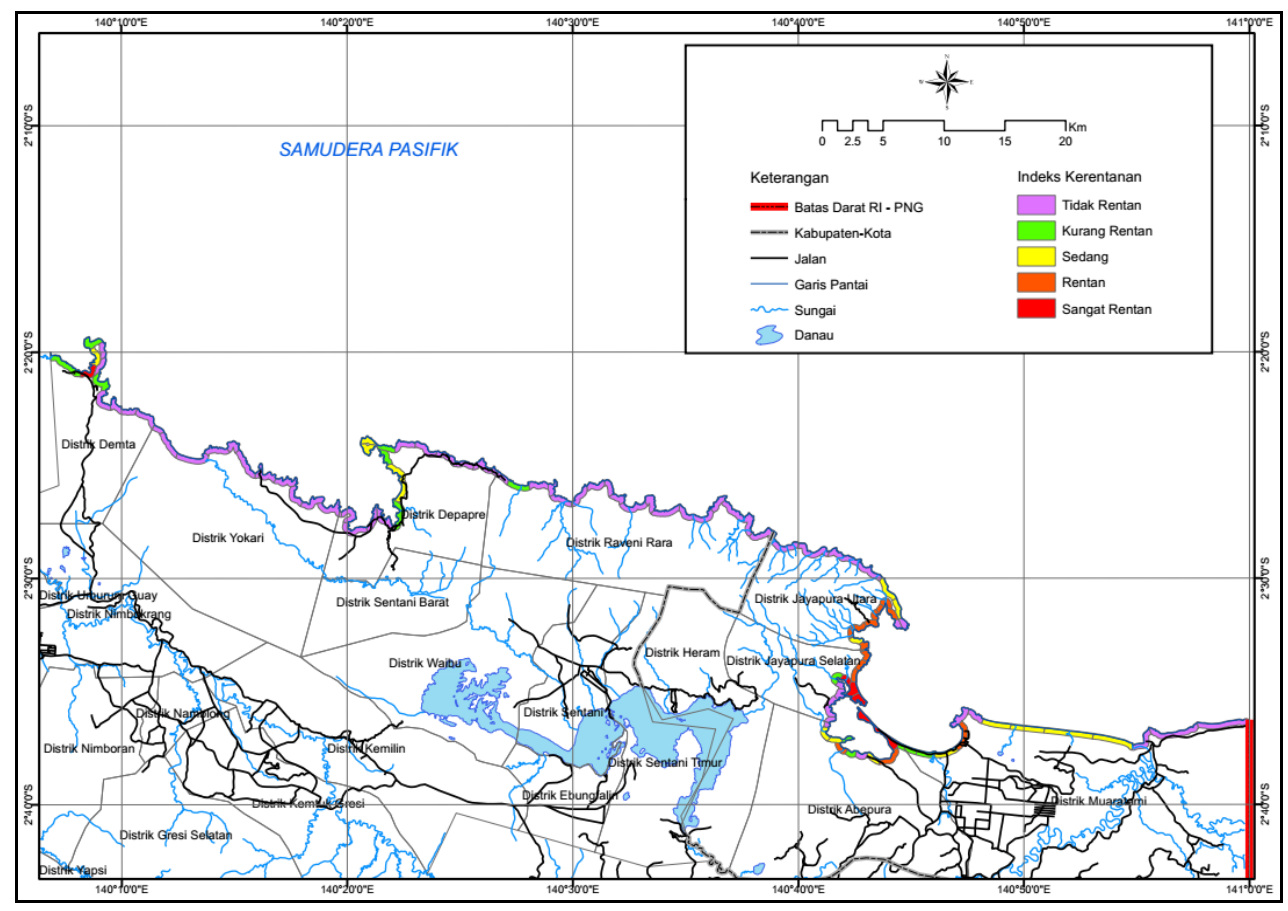

Sumber: Hasil Analisis, 2017

Gambar 2. Peta Kerentanan Tutupan Lahan Pesisir Kota dan Kabupaten Jayapura

\section{Tingkat Kerentanan Elevasi Pesisir}

Berdasarkan peta elevasi wilayah Jayapura yang diekstrak dari citra SRTM, terdapat perbedaan profil elevasi antar wilayah (Gambar 3). Kota Jayapura memiliki bentuk elevasi yang relatif bervariasi, dengan sejumlah dataran rendah dan pantai, juga terdapat perbukitan dan gunung-gunung, dengan tingkat kemiringan sekitar 40 derajat. Elevasi tertinggi wilayah Kota Jayapura sekitar $>1500$ meter dpl (di atas permukaan laut). Wilay ah tersebut sebagian kecil masih termasuk dalam wilayah Pegunungan Cyclops. Rata-rata 


\section{Kajian Kerentanan Wilayah Pesisir Ditinjau dari Geomorfologidan Elevasi Pesisir...}

wilayah tertinggi Kota Jayapura sekitar 500 meter dpl yang terdapat di Distrik Jayapura Utara, sedangkan wilayah lainnya rata-rata berada pada ketinggian 100-10 meter dpl. Sebaliknya, sebagian besar wilayah Kabupaten Jayapura dominan berada pada elevasi yang lebih tinggi, yaitu di Pegunungan Cyclops yang memiliki beberapa puncak yang tinggi, puncak tertinggi adalah Puncak Rafeni (1.880 meter dpl), Puncak Rara (1.700 meter dpl) dan Puncak Dafonsoro (1.530 meter dpl) (Richards \& Suryadi, 2002). Selain itu, pada wilayah pesisir Kabupaten Jayapura terdapat pula wilayah pesisir dengan elevasi yang rendah hingga sedang, seperti di beberapa titik wilayah pesisir Distrik Depapre dan Distrik Demta.

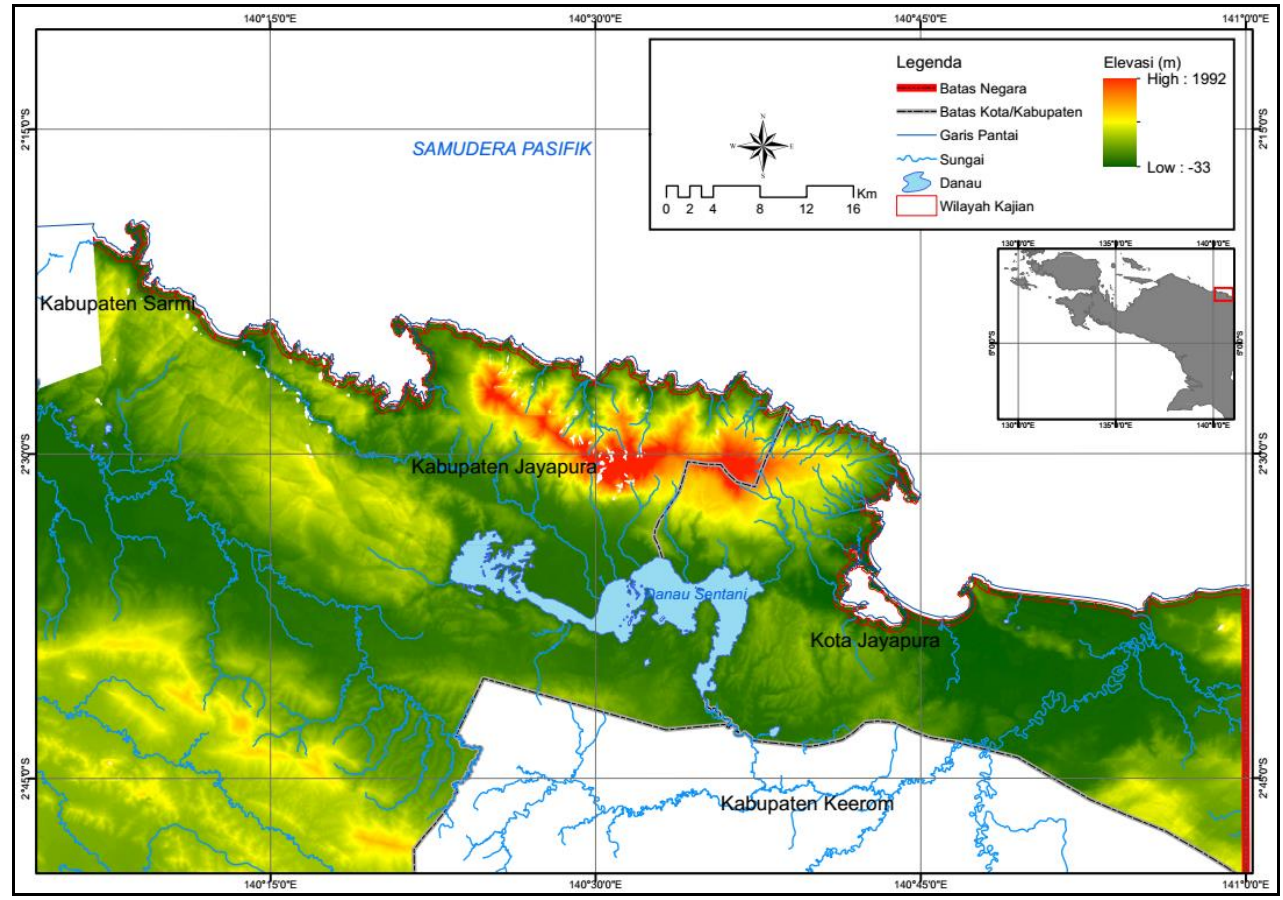

Sumber: Hasil Analisis, 2017

\section{Gambar 3. Peta Elevasi Kota dan Kabupaten Jayapura}

Aspek elevasi wilayah pesisir merupakan salah satu parameter yang dapat menentukan potensi terhadap bahaya terjadinya penggenangan dan kecepatan maju atau mundurnya garis pantai. Elevasi wilayah pesisir dapat mempengaruhi seberapa luas genangan air laut yang diakibatkan oleh kenaikan muka laut. Menurut Marwasta \& Priyono (2007), apabila terjadi gelombang pasang maka pantai atau pesisir dengan morfologi landai (elevasi rendah) dapat menyebabkan air akan masuk ke daratan relatif jauh sehingga luapan airnya sangat luas. Oleh karena itu, hasil analisis elevasi wilayah pesisir bahwa sebagian wilayah pesisir Kota Jayapura termasuk kategori yang cenderung rentan terhadap terjadinya genangan akibat kenaikan muka air laut. Semakin rendah elevasi suatu wilayah pesisir yang ada di Kota dan Kabupaten Jayapura, maka semakin besar peluang terjadinya genangan air laut akibat gelombang laut ataupun kenaikan muka air laut.

Dari hasil analisis tingkat kerentanan ketinggian elevasi setiap sel wilayah kajian pada Gambar 4, sebagian besar wilayah kajian pesisir Kota Jayapura merupakan wilayah pesisir yang landai, sedangkan pada wilayah kajian Kabupaten Jayapura didominasi oleh elevasi yang tinggi. Sekitar $57,45 \%(136,99 \mathrm{~km})$ wilayah kajian termasuk dalam kategori tidak rentan, kategori kurang rentan 20,06\% (47,84 km), kategori sedang 9,40\% $(22,43 \mathrm{~km})$, kategori rentan $7,51 \%(17,91 \mathrm{~km})$ dan hanya $5,57 \%(13,28 \mathrm{~m})$ dalam kategori sangat rentan. 
Berdasarkan Gambar 4, hampir sebagian wilayah pesisir Distrik Abepura dan Distrik Jayapura Selatan termasuk dalam kategori rentan karena berada pada elevasi yang rendah (0-10 meter). Kategori tidak rentan berada pada wilayah pesisir yang berupa perbukitan tinggi ( $>30$ meter) yang terdapat di bagian utara Distrik Jayapura Utara, bagian timur Distrik Muaratami dan dalam kawasan Teluk Youtefa (termasuk dalam wilayah Distrik Abepura dan Distrik Jayapura Selatan). Dengan demikian, sebagian besar wilayah kajian pada pesisir Kabupaten Jayapura termasuk dalam kategori tidak rentan. Hal ini disebabkan karena wilayah kajian terutama Distrik Revani Rara dan Distrik Depapre merupakan daerah pesisir dengan elevasi yang sangat tinggi karena merupakan wilay ah Pegunungan Cyclops. Begitupun wilayah pesisir Distrik Yokari yang merupakan daerah perbukitan dan dataran yang cukup tinggi sehingga masuk dalam kategori kurang rentan dan tidak rentan.

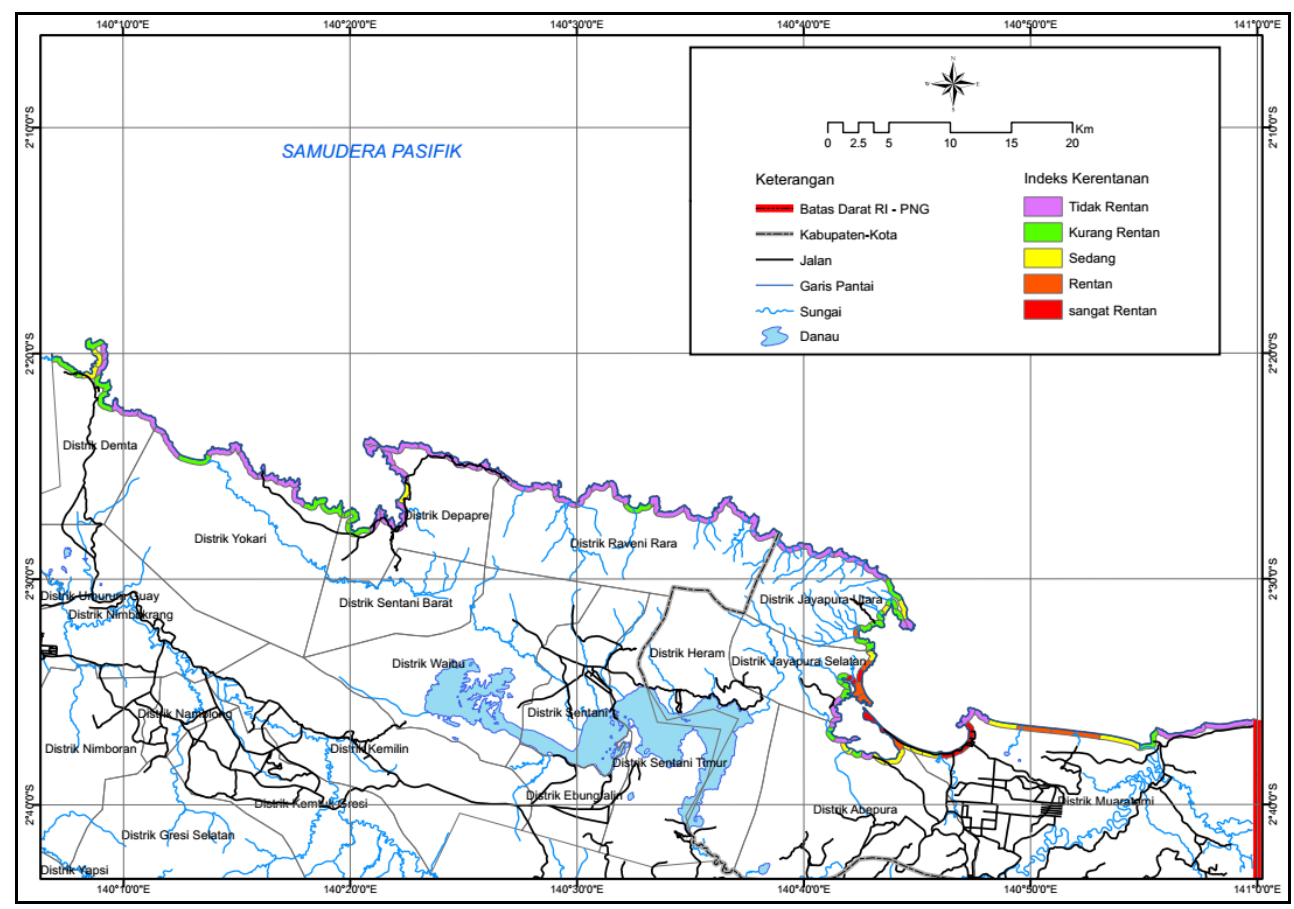

Sumber: Hasil Analisis, 2017

\section{Gambar 4. Peta Kerentanan Elevasi Wilayah Pesisir Kota dan Kabupaten Jayapura}

\section{Indeks Kerentanan Wilayah Pesisir Kota dan Kabupaten Jayapura}

Peta tingkat kerentanan wilayah pesisir dari bentuk geomorfologi dan elevasi pesisir pada Kota dan Kabupaten Jayapura pada Gambar 5, diketahui bahwa wilayah-wilayah yang termasuk kategori sangat rentan adalah sebagian wilayah pesisir Distrik Abepura, Distrik Jayapura Selatan dan sebagian kecil Distrik Muaratami, Kota Jayapura. Pada wilayahwilayah tersebut didominasi oleh vegetasi pesisir (hutan mangrove) yang sangat rentan terhadap perubahan dan terdapat pada wilayah pesisir dengan elevasi yang sangat rendah. Wilayah pesisir yang termasuk kategori rentan hingga sedang sebagian besar dipengaruhi oleh eleva pesisir yang rendah dan juga adanya karena pemukiman penduduk di wilayah pesisir. Selanjutnya wilayah pesisir dalam kategori tidak rentan dan kurang rentan pada umumnya berada pada wilayah pesisir dengan elevasi tinggi. Sebagian besar wilayah pesisir dalam kategori tersebut masih berada dalam wilayah Pegunungan Cyclops.

Berdasarkan indeks kerentanan wilayah pesisir yang diperoleh dalam penelitian ini, sebagian besar wilayah pesisir Kota dan Kabupaten Jayapura apabila ditinjau dari bentuk 
geomorfologi dan elevasi pesisir masih termasuk dalam kategori tidak rentan sepanjang $145,88 \mathrm{~km}(61,18 \%)$, kategori kurang rentan $33,14 \mathrm{~km}(13,90 \%)$ dari total garis pantai wilayah kajian, kategori sedang 29,03 km (12,17\%), kategori rentan 12,12 km (5,08\%) dan kategori sangat rentan 18,29 km (7,67\%) (Gambar 6). Dari hasil analisis tersebut, sekitar $41,17 \mathrm{~km}$ wilayah pesisir Kota Jayapura termasuk kategori tidak tidak rentan, kategori kurang rentan $11,00 \mathrm{~km}$, kategori sedang $25,47 \mathrm{~km}$, kategori rentan 10,13 km dan kategori sangat rentan $18,29 \mathrm{~km}$. Wilayah pesisir Kabupaten Jayapura hanya termasuk dalam kategori tidak rentan $104,71 \mathrm{~km}$, kategori kurang rentan $22,15 \mathrm{~km}$, kategori sedang 3,55 km dan kategori rentan hanya 2,00 km. Berdasarkan hasil tersebut dapat disimpulkan bahwa sebagian besar wilayah pesisir Kabupaten Jayapura merupakan wilayah yang tidak rentan, sedangkan wilayah pesisir Kota Jayapura tergolong cukup rentan.

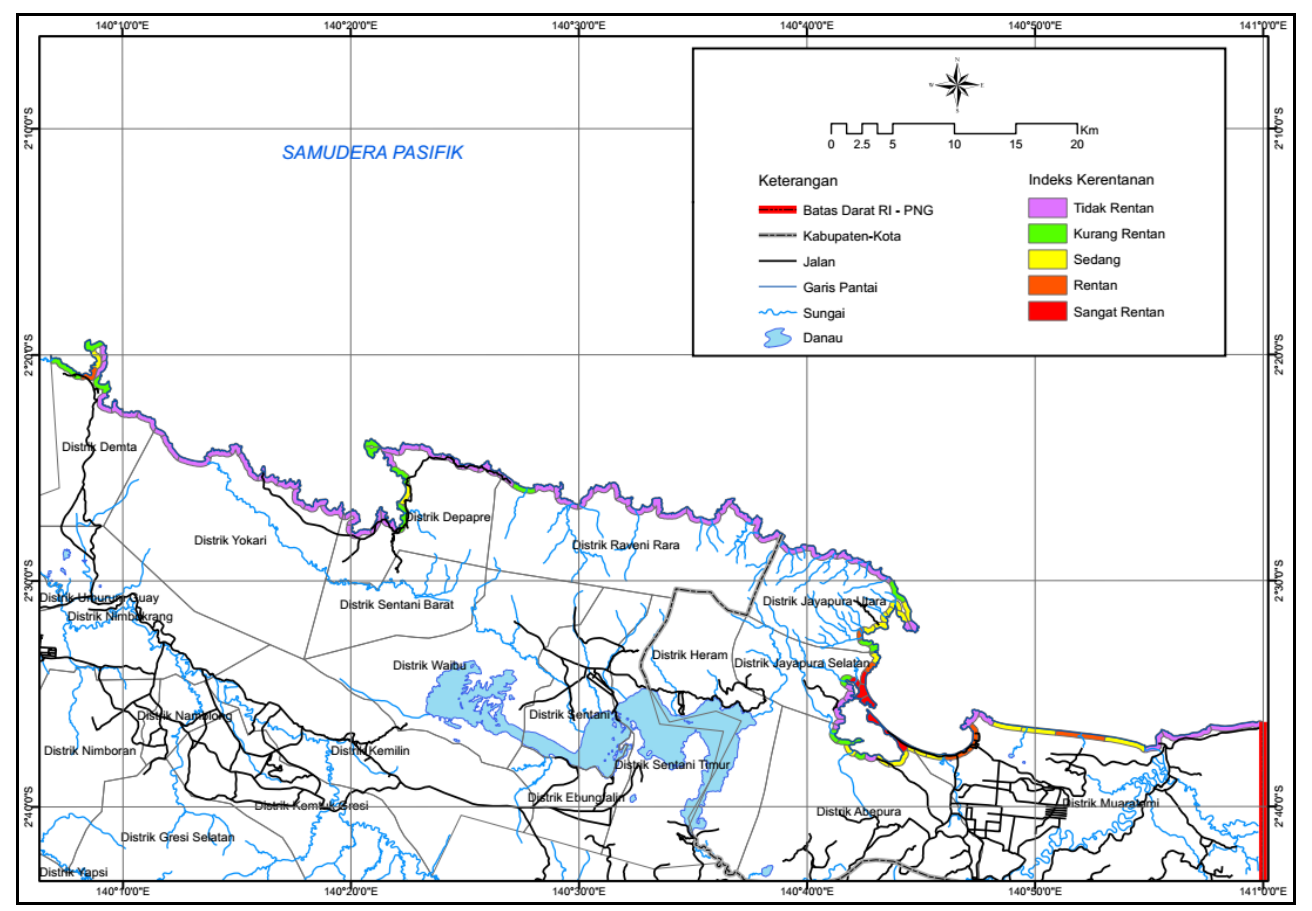

Sumber: Hasil Analisis, 2017

Gambar 5. Peta Indeks Kerentanan Wilayah Pesisir Kota dan Kabupaten Jayapura

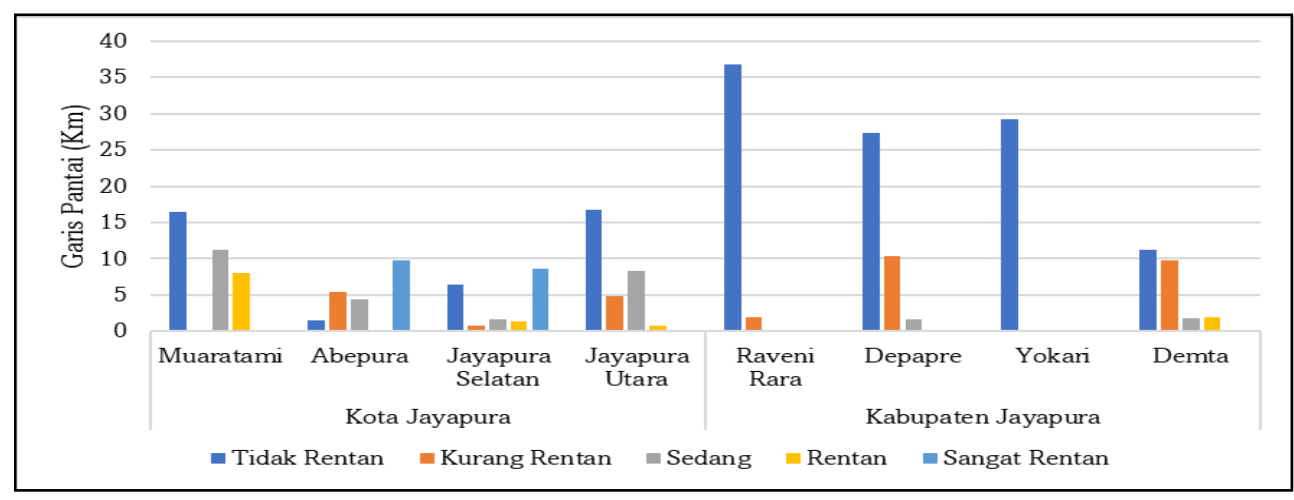

Sumber: Hasil Analisis, 2017

\section{Gambar 6. Distribusi Indeks Kerentanan Wilayah Pesisir Berdasarkan Panjang Garis Pantai}


Indeks kerentanan pesisir dapat digunakan sebagai indikator tingkat kerentanan suatu wilayah pesisir. Menurut Kaiser (2007), kerentanan pesisir merupakan suatu kondisi yang menggambarkan keadaan mudah terkena dari suatu sistem alami serta keadaan sosial pesisir (manusia, kelompok atau komunitas) terhadap bencana pantai. Tingkat kerentanan merupakan suatu hal yang penting untuk diketahui karena dapat berpengaruh terhadap terjadinya bencana. Proporsi setiap kategori indeks kerentanan dapat menjadi petunjuk karakteristik spasial jenis variabel ataupun cakupan tingkat atau kategori kerentanan pada suatu kawasan. Menurut Kasim \& Siregar (2012), proporsi ranking jenis variabel yang bervariasi menunjukkan bahwa keragaman karakteristik spasial variabel tersebut bersifat lokal (relatif) pada skala lokasi penilaian. Sebaliknya, jenis ranking variabel yang hampir konstan atau konstan sepanjang garis pantai yang dinilai menunjukkan bahwa jenis variabel tersebut berkarakter regional hingga global. Hal ini pun dapat dilihat pada tingkat kerentanan wilayah pesisir Kota dan Kabupaten Jayapura walaupun pada beberapa wilayah pesisir Kota Jayapura tergolong kategori sangat rentan dan rentan, namun secara keseluruhan bahwa wilayah pesisir Kota dan Kabupaten Jayapura yang termasuk dalam wilayah kajian masih tergolong tidak rentan dan kurang rentan dengan persentasi yang lebih tinggi (sekitar 75,07\%).

Kondisi tingkat kerentanan wilayah pesisir yang dihasilkan pada penelitian ini diprediksi masih bisa mengalami perubahan seiring dengan tingginya tingkat pembangunan, terutama di wilayah pesisir Kota Jayapura. Hal ini sangat memungkinkan karena wilayah pesisir Kota Jayapura merupakan wilayah yang dijadikan sebagai pusat pengembangan infrastruktur, kegiatan perekonomian Kota Jayapura dan Provinsi Papua, perluasan wilayah, serta pertambahan penduduk. Kondisi ini akan berakibat pada terjadinya tekanan yang cukup besar terhadap kondisi lingkungan di sekitar pesisir dan sepanjang wilayah pesisir Kota Jayapura. Terkait dampak pertambahan penduduk, hal tersebut sejalan dengan Wibowo \& Supriatna (2011) yang menyatakan bahwa kondisi lingkungan pantai sebagian besar kota pesisir di Indonesia rentan akibat aktivitas manusia. Semakin tinggi jumlah pertambahan penduduk, maka semakin tinggi pula tingkat kerentanan lingkungan pantainya. Selain itu, wilayah pesisir Kota dan Kabupaten Jayapura merupakan kawasan yang rawan gelombang pasang dan tsunami karena posisi wilayah pesisir yang relatif terbuka terhadap gelombang yang datang dari Samudera Pasifik. Menurut Dahlan (2014), beberapa wilayah pesisir Kota Jayapura telah mengalami abrasi akibat gelombang laut dan bahkan pemukiman penduduk di wilayah pesisir Skouw Distrik Muaratami telah mengalami relokasi berulang-ulang akibat terjadi abrasi di sekitar permukiman penduduk. Pada penelitian ini diperoleh bahwa ketinggian elevasi pada wilayah pesisir diduga memberikan pengaruh yang sangat besar terhadap tingkat kerentanan pesisir Kota dan Kabupaten Jayapura. Beberapa hasil penelitian kerentanan wilayah pesisir juga telah menunjukkan bahwa ketingggian elevasi suatu wilayah pesisir merupakan faktor penting yang akan berpengaruh terhadap tingkat kerentanan pesisir (Rositasari, Setiawan, Supriadi, Hasanuddin, \& Prayuda, 2011; Sinaga, Surbakti, \& Nugraha, 2013; Tejakusuma, 2011), karena aspek elevasi wilayah pesisir dapat menandakan tingkat kelemahan wilayah pesisir tersebut terhadap bahaya abrasi, penggenangan air dan kecepatan perubahan garis pantai. Selanjutnya, Dhiauddin, Gemilang, \& Wisha (2017) menyatakan bahwa walaupun suatu wilayah pesisir berbatasan langsung dengan samudera, namun dengan kemiringan pantai yang terjal akan berpengaruh terhadap perhitungan indeks kerentanan. Oleh karena itu, apapun bentuk tutupan dan penggunaan lahan pada suatu wilayah pesisir, namun dengan ketinggian elevasi wilayah pesisir yang rendah, maka akan memberikan peluang atau berdampak akan terjadinya genangan air laut, terutama akibat kenaikan muka air laut. 


\section{Kajian Kerentanan Wilayah Pesisir Ditinjau dari Geomorfologidan Elevasi Pesisir...}

\section{Kesimpulan}

Kajian tingkat kerentanan wilayah pesisir Kota dan Kabupaten Jayapura menghasilkan luaran berupa gambaran wilayah rentan secara spasial, baik kondisi kerentanan dari aspek geomorfologi, elevasi maupun indeks tingkat kerentanan dari kedua aspek tersebut. Secara keseluruhan, tingkat kerentanan wilayah pesisir Kota dan Kabupaten Jayapura dikelompokkan dalam 5 kelas kategori, yaitu sepanjang 145,88 km wilayah pesisir Kota dan Kabupaten Jayapura yang menjadi wilayah kajian termasuk kategori tidak rentan, $33,14 \mathrm{~km}$ termasuk kategori kurang rentan, 29,03 km termasuk kategori sedang, 12,12 km termasuk kategori rentan, dan 18,29 km termasuk kategori sangat rentan. Wilayah pesisir yang dianggap rentan adalah wilayah pesisir Distrik Abepura, Distrik Jayapura Selatan dan Distrik Muaratami, sedangkan hampir sepanjang wilayah pesisir Kabupaten Jayapura dengan elevasi yang relatif tinggi termasuk kategori tidak rentan. Ketinggian elevasi wilayah pesisir memberikan pengaruh yang sangat besar terhadap tingkat kerentanan pesisir, karena elevasi pesisir dapat menandakan tingkat kelemahan suatu wilayah pesisir terhadap bahaya penggenangan air.

\section{Daftar Pustaka}

Abidin, H. Z., Andreas, H., Gumilar, I., Sidiq, T. P., Gamal, M., Murdohard ono, D., ... Fukuda, Y. (2010). Studying land subsidence in Semarang (Indonesia) using geodetic methods. In FIG Congress 2010: Facing the Challenges - Building the Capacity (pp. 11-16). Sydney, Australia: FIG Congress. Retrieved from https://www.researchgate.net/publication/242692619_Studying_Land_Subsidence_in_Semarang_Indo nesia_Using_Geodetic_Methods.

Agustin, S., Syamsidik, S., \& Fatimah, E. (2016). Penilaian indeks kerentanan fisik wilayah pesisir pantai barat selatan Aceh. Jurnal Teknik Sipil, 5(1), 71-80. Retrieved from http://prodipps.unsyiah.ac.id/Jurnalmts/images/Jurnal/volume/vol5/5.1.mts/7. 71-80 Shinta Agustin.pdf.

Beatley, T., Brower, D., \& Schwab, A. K. (2002). An introduction to coastalzone management(Second). Island Press.

Dahlan, D. (2014). Analisis mitigasi bencana lingkungan laut dan pesisir Kota Jayapura. The Journal of Fisheries Development, $1(1), \quad 13-26 . \quad$ Retrieved from http://jurnal.uniyap.ac.id/index.php/Perikanan/article/download/255/245.

Dhiauddin, R., Gemilang, W. A., \& Wisha, U. J. (2017). Pemetaan kerentanan pesisir Pulau Simeulue dengan metode CVI (coastal vulnerability index). EnviroScienteae, 13(2), 157-170. Retrieved from http://ppjp.unlam.ac.id/journal/index.php/es/article/view/3918.

Dwiprabowo, H., Djaenudin, D., Alviya, I., \& Wicaksono, D. (2014). Dinamika tutupan lahan: Pengaruh faktor sosial ekonomi. (I. Las \& Y. Rahayu, Eds.). Sleman: PT. Kanisius.

Fletcher, S., \& Smith, H. D. (2007). Geography and coastal management. Coastal Management, 35(4), 419-427. doi:10.1080/08920750701525750.

Gornitz, V. (1990). Vulnerability of the East Coast, U.S.A. to future sea level rise. Journal of Coastal Research, 9 , 201-237.

Gornitz, V. (1991). Global coastal hazards from future sea-level rise. Palaeogeography, Palaeoclimatology, Palaeoecology (Global and Planetary Change Section), 89(4), 379-398. doi:10.1016/09218181(91)90118-g.

Gornitz, V. M., \& White, T. W. (1992). A coastal hazards data base for the U.S. east coast (Environmental Sciences Division). Environmental Sciences Division. Tennessee. doi:10.3334/CDIAC/ssr.ndp043a.

Joesidawati, M. I. (2016). Penilaian kerentanan pantai di wilayah pesisir Kabupaten Tuban terhad ap an caman 
kerusakan. Jurnal Kelautan, $9(2), \quad$ 188-198. $\quad$ Retrieved from http://journal.trunojoyo.ac.id/jurnalkelautan/rt/printerFriendly/1667/0.

Kaiser, G. (2007). Coastal vulnerability to climate change and natural hazards. ForumDKKV/CEDIM:Disaster Reduction in Climate Change(Vol. 49). Retrieved from http://www.cedim.de/download/39_Kaiser.pdf.

Kaly, U., Pratt, C., \& Mitchell, J. (2004). The Environmental Vulnerability Index (EVI) (SOPAC Technical Report 384). Retrieved from http://gsd.spc.int/sopac/evi/Files/EVI 2004 Technical Report.pdf.

Kasim, F., \& Siregar, V. P. (2012). Penilaian kerentanan pantai menggunakan metode integra si CVI-MCA studi kasus pantai Indramayu. Forum Geografi, 26(1), 65-76. doi:10.23917/forgeo.v26i1.5051.

Kementerian Kelautan dan Perikanan Republik Indonesia (KKP). (2016). Peraturan Menteri Kelautan dan Perikanan Republik Indonesia Nomor 23/PERMEN-KP/2016 Tentang Perencanaan Pengelolaan Wilayah Pesisir dan Pulau-Pulau Kecil. Jakarta: Pemerintah Republik Indonesia.

Marfai, M. A., \& King, L. (2008). Potential vulnerability implications of coastal inundation due to sea level rise for the coastal zone of Semarang city, Indonesia. Environmental Geology, 54(6), 1235-1245. doi:10.1007/s00254-007-0906-4.

Marwasta, D., \& Priyono, K. D. (2007). Analisis karakteristik permukiman desa-desa pesisir di Kabupaten Kulonprogo. Forum Geografi, 21(1), 57-68. Retrieved from http://journals.ums.ac.id/index.php/fg/article/view/1819.

Pemerintah Kota Jayapura. (2013). Rencana Tata Ruang Wilayah (RTRW) Kota Jayapura 2013-2033. Jayapura: Pemerintah Kota Jayapura.

Pemerintah Republik Indonesia. (2007). Undang-Undang Republik Indonesia Nomor 27 Tahun 2007 tentang Pengelolaan Wilayah Pesisir dan Pulau-Pulau Kecil. Jakarta: Sekretaris Negara Republik Indonesia.

Pendleton, E. A., Thieler, E. R., \& Williams, S. J. (2005). Coastal vulnerability assessment of gateway national recreation area (GATE) to sea-level rise. Denver. Retrieved from https://pdfs.semanticscholar.org/9f2d/65cd2986ff3bb3dfc918f57fed498deab5ea.pdf.

Pendleton, E. A., Thieler, E. R., \& Williams, S. J. (2010). Importance of coastal change variables in determining vulnerability to sea- and lake-level change. Journal of Coastal Research, 261(261), 176-183. doi:10.2112/08-1102.1.

Prabowo, H., \& Astjario, P. (2012). Perencanaan pengelolaan wilayah pesisir Pulau Jawa ditinjau dari aspek kerentanan kawasan dan implikasinya terhadap kemungkinan bencana kenaikan muka laut. Jurnal Geologi Kelautan, 193), 167-174. http:// ejournal.mgi.esdm.go.id/index.php/jgk/article/view/225.

Putra, A., Husrin, S., Tanto, T. Al, \& Pratama, R. (2015). Kerentanan pesisir terhadap perubahan iklim di timur laut Provinsi Bali. Majalah Ilmiah Globe, 171), 43-50. Retrieved from http://jurnal.big.go.id/index.php/GL/article/view/217.

Rositasari, R., Setiawan, W. B., Supriadi, I. H., Hasanuddin, H., \& Prayuda, B. (2011). Kajian dan prediksi kerentanan pesisir terhadap perubahan iklim: Studi kasus di pesisir Cirebon. Jurnal Ilmu dan Teknologi Kelautan Tropis, 3(1), 52-64. Retrieved from http://repository.ipb.ac.id/handle/123456789/53397.

Sakka, S., \& Muzaki, A. A. (2010). Modul Pelatihan Pembangunan Indeks Kerentanan Pantai: Pengolahan Data Geomorfologi Pantai. Retrieved from https://anzdoc.com/modul-pelatihanppikpe33ce2feee440d5898659c45d845ff5b80268.html.

Sakka, S., Paharuddin, P., \& Rupang, E. (2014). Analisis kerentanan pantai berdasarkan coastal vulnerability index (CVI) di pantai Kota Makassar. Torani (Jurnal Ilmu Kelautan dan Perikanan), 24(3), 49-53. Retrieved from http://journal.unhas.ac.id/index.php/torani/article/download/237/131.

Sinaga, R., Surbakti, H., \& Nugraha, R. B. A. (2013). Penentuan indeks kerentanan pantai akibat kenaikan mu ka laut di pantai bagian barat Provinsi Banten. Maspari Journal, 5(1), 40-43. Retrieved from http://eprints.unsri.ac.id/5181/3/6._Romega.pdf.

Syah, A. F. (2013). Pengukuran daerah genangan di pesisir Bangkalan akibat naiknya muka air laut. Jurnal 
14 Kajian Kerentanan Wilayah Pesisir Ditinjau dari Geomorfologidan Elevasi Pesisir...

Ilmiah Perikanan dan Kelautan, 5(1), 67-71. Retrieved from http://journal.unair.ac.id/filerPDF/abstrak_511116_tpjua.pdf.

Tejakusuma, I. G. (2011). Pengkajian kerentanan fisik untuk pengembangan pesisir wilayah Kota Makassar. Jurnal Sains dan Teknologi Indonesia, 13(2), 82-87. Retrieved from http://ejurnal.bppt.go.id/index.php/JSTI/article/view/882.

Ward, P. J., Marfai, M. A., Yulianto, F., Hizbaron, D. R., \& Aerts, J. C. J. H. (2011). Coastal inundation and damage exposure estimation: A case study for Jakarta. Natural Hazards, 56(3), 899-916. doi:10.1007/s11069-010-9599-1.

Wibowo, A., \& Supriatna, S. (2011). Kerentanan lingkungan pantai kota pesisir di Indonesia. Jurnal Ilmu dan Teknologi Kelautan Tropis, 3(2), 1-20. $\quad$ Retrieved from http:/ / download.portalgaruda.org/article.php?article=155079\&val=236\&title=KERENTANAN LINGKUNGAN PANTAI KOTA PESISIR DI INDONESIA. 